\title{
Anti-HIV / HCV Activity of Cyanobacterial Phycobiliproteins by a New Standardized Method Using Bacteriophage Surrogates
}

\author{
MOHAMMAD I. ABD EL HAMID ${ }^{1}$, WALAA M. ABD EL FATAH ${ }^{1}$, ADEL A. EL MORSI ${ }^{1}$, MOHAMED SHEHATA DRAZ ${ }^{2}$, \\ SHANTANU KALLAKURI ${ }^{2}$, SIMONA BUNGAU ${ }^{3 *}$, LAURA ENDRES ${ }^{3 *}$, CRISTINA BARDACA (URDUCEA) ${ }^{4}$, ELSAYED E. HAFEZ ${ }^{5}$ \\ ${ }^{1}$ Faculty of Science, Mansoura University, Egypt. \\ 2Brigham and Women's Hospital, Harvard Medical School, Boston, USA \\ 3University of Oradea, Faculty of Medicine and Pharmacy, 1 Decembrie Sq., 410087, Oradea, Romania \\ 4Politehnica University of Bucharest, Faculty of Applied Chemistry and Materials Science, 1-7 Gh. Polizu Str., 011061, Bucharest, \\ Romania \\ ${ }^{5}$ City of Scientific Research and Technology Applications, Borg El Arab, Alexandria, Egypt
}

\begin{abstract}
The control of the viral infections requires efficient, rapid and safe testing procedures. We tested the efficiency of a quick and reliable alternative assay to the standard plaque assay (PA) in the detection of viral inhibition. Using MS-2 and $\Phi X-174$ phages, the developed assay was used to evaluate the potential of cyanobacterial phycobiliproteins (PBS) as natural antiviral bioactive molecules against HIV and HCV. The antiviral activity was examined by mixing the phage with crude aqueous extracts in a 1:1 ( $/ / \mathrm{V})$ ratio for $1 \mathrm{hr}$ at $4^{\circ} \mathrm{C}$. The viral titer of MS-2 and $\Phi X-174$ was reduced by $0.92 L R$ and $1.19 L R$, respectively. In the case of the crude PBS extract of Spirulina platensis, similar result trends were obtained by virion titration which indicated that a strong correlation between the two assays was verified $(\geq 90 \%)$. The morphological characteristics of both phages were severely affected when treated with the extract, whereas the characteristic features of their hosts seem unaffected. The PBS was found to affect the adsorption of the phages on their bacterial hosts and consequently viral reproduction. In conclusion, MS-2 and $\Phi X-174$ can be used in drug evaluation by the well standardized method developed in this study.
\end{abstract}

Keywords: Antiviral assay, surrogates, MS-2, $\Phi X-174$, phycobiliproteins, cyanobacteria, virion titration

Bacteriophages are ubiquitous entities [1], nonpathogenic to human beings [2], easy to be cultured and detectable with unsophisticated laboratory methods [3]. Phages have been used as a workhorse in various biotechnological fields [4] including studies of DNA replication, gene expression and regulation, therapy and prevention, viral morphogenesis, and epidemiology [4]. The most interesting recent applications focused on using suitable phages as surrogates for highly contagious viruses in many studies [4].This simulation is based on an architecture where both the mammalian viruses, and phages must be similar to each other, primarily in genome composition, size and replication modes [6].The bacteriophage MS-2 is a small ( $25 \mathrm{~nm}$ ), tail-less, naked icosahedral (20-sided structure), single stranded RNA bacteriophage that belongs to the Leviviradae family [2] It is specific to male E. coli (F-pilus) [7]. Its RNA genome composed of 3569 bases [8]. MS-2 has also been used as a viral surrogate to human viruses, including polovirus, enterovirus and hepatitis A virus [9]. The phage $\Phi X-174$ belongs to the Microviridae family and is a positive sense, circular/linear, single stranded (ss) DNA [10]. Its genome is encapsulated in a $25 \mathrm{~nm}$ icosahedral protein capsid and has 5386 nucleotides [10]. $\Phi X-174$ primarily infects its host, Escherichia coli $C$ strain (E. coli C), and can also be used as a model for HBV, HCV and HIV [11].

The use of natural antiviral bioactive molecules may combat the rapidly evolving viral drug resistance. For instance, acyclovir (ACV), as an antiviral drug, has drastically lost its specificity and efficacy for many patients, due to the development of human simplex virus (HSV) resistant strain [12]. Similarly, ribavirin (RBV) has been under use to treat HSV [13] as well as HCV, but recent studies show that chronic HCV patients exhibit resistance to RBV $[14,15]$. Nearly all antiviral mechanisms of RBV require its import into the cell, and consequently, cytotoxicity and damage to the host chromosomes is a highly probable result [12].

Cyanobacteria have gained much attention as rich resource of a variety of natural bioactive compounds that exhibit a broad spectrum of antiviral activity [16-19]. Cyanobacterial bio-active molecules include, to name a few, calcium spirulan (Ca-SP) from Spirulina platensis, cyanovirin from Nostoc ellipsosporum and a cyclic polypeptide produced by Lyngbya majuscule $[16,17,19,20]$. Phycobiliproteins (PBS) are accessory photosynthetic pigments found in cyanobacteria, red algae and cryptophytes [21]. They are located in the thylakoid membranes beside the reaction center of the photosystem II (PSII). PBS consist of allophycocyanin, phycocyanin and phycoerythrin [22]. They perform an important function by acting as light-harvesting complexes that transfer the energy of sunlight into chlorophyll in the thylakoid membranes. It is water-soluble and can easily be isolated and separated as pigment-protein complexes from other lipid soluble pigments [23]. PBS have been widely used in biomedical research as fluorescent markers [24,25], and for the preparation of the antimicrobial and anti-cancer therapeutics $[26,27]$.

For decades, the laboratory characterization of bacteriophage growth has been conducted by the plaque assay (PA) as the mostreliable technique [28]. Few studies have paid attention to the virion titration methods for the detection of viral concentrations [29-31]. In this context, the present investigation focuses on exploring the antiviral potential of cyanobacterial PBS by utilizing a simple spectrophotometric technique to compare its precision with classical plaque assay methods, in detection of viral inhibition of crude aqueous extracts of six different cyanobacterial species against MS-2 and $\Phi X-174$ phages, as reliable surrogates of specific virulent human viruses. 


\section{Materials and methods}

\section{Tested cyanobacteria}

The cyanobacterial species were isolated from water samples collected along the eastern branch of the Nile river, at the delta region close to Mansoura University $\left(31^{\circ}\right.$ $\left.2^{\prime} 45.7620^{\prime \prime} \mathrm{N}, 31^{\circ} 2^{\prime} 18.6444 " \mathrm{E}\right)$ (EPA, 1985). The algal isolates were obtained from the culture collection of the Biotech International Research and Development (BIRD) Centre, Mansoura, Egypt (https://www.petrotechffn.com) and grown on Naviculanutrientmedium [32]. The cultures were incubated for three weeks at $25 \pm 1^{\circ} \mathrm{C}$ under $1.2 \pm$ 0.2 Klux light intensity with continuous illumination provided by white, cool fluorescent tubes [33]. The growth was monitored every three days, to calculate the growth rate and generation time.

\section{Biomass harvesting and spectrophotometric measurements of phycobiliproteins}

The cyanobacterial biomass was harvested by centrifugation at $4000 \mathrm{rpm}$ for $10 \mathrm{~min}$ [34] and washed twice with double distilled water. One gram of fresh biomass was suspended in $100 \mathrm{~mL}$ of $0.1 \mathrm{M}$ sodium phosphate ( $p H \mathrm{7.0})$, that contained $1 \mathrm{mM}$ sodium azide, and subjected to $4 \mathrm{~h}$ freezing and thawing cycles [35]. The clear supernatant was collected after centrifugation (4000 rpm for $10 \mathrm{~min}$ at $4^{\circ} \mathrm{C}$ ), for spectrophotometeric analysis, and then lyophilized and stored until needed.

Using a Unico UV-2000, UV-Vis spectrophotometer, the absorbance of phycocyanin (C-PC), allophycocyanin (APC) and phycoerythrin (PE) in the supernatantwere measured, at wavelengths 620,652 , and $562 \mathrm{~nm}$ respectively. The concentration of each pigment was calculated using the following the equations [36]:

$C-P C\left(\mathrm{mg} \mathrm{mL}^{-1}\right)=\left[\mathrm{A}_{620}-0.474 \mathrm{~A}_{652}\right] / 5.34$

APC $\left(\mathrm{mg} \mathrm{mL}^{-1}\right)=\left[\mathrm{A}_{652}-0.208 \mathrm{~A}^{652}\right] / 5.09$,

PE $\left(\mathrm{mg} \mathrm{mL}^{-1}\right)=\left[\mathrm{A}_{562}-2.41 \mathrm{PC}-0.849 \mathrm{APC}\right] / 9.62$

The purity of phycocyanin extracts were evaluated by the ratios $A_{620} / A_{280}[35,36]$.

\section{IR spectra of aqueous cyanobacterial phycobiliproteins}

The IR spectra of the freeze-dried extracts were estimated by a Nicolet iS10IR spectrophotometer. Sodium Dodecyl Sulphate Polyacrylamide Gel Electrophoresis (SDS-PAGE) analysis was performed using a polyacrylamide slab gel with $1.5 \mathrm{~mm}$ thickness. A $300 \mu \mathrm{L}$ of sample loading buffer was added to the samples, and pre-incubated for about 5-10 min at $95^{\circ} \mathrm{C}$, followed by cooling on ice. The crude PBS extract, standard C-PC (Sigma Phycocyanin), and the protein ladder (MW P04, Nippon Genetics Europe Gmbh, Germany) were loaded into separate wells that were filled carefully with electrode buffer of $\mathrm{pH} 8.3$ using a micropipette. Vertical gel electrophoresis was carried out at room temperature for $2 \mathrm{~h}$, at 115 Volt, and then the gel was washed and overlaid with gel fix solution in a plastic container, to preventany possible out washing of the protein during gel staining. The gel was visualized by staining with Coomassie brilliant blue R-250. A de-staining solution was used for de-staining of the gel. Staining and de-staining of the gel were carried out on a rocking platform, for $2 \mathrm{~h}$. The molecular weights of protein subunits were determined by using a protein marker $[37,38]$.

\section{Antiviral assays of the extracted PBS}

Bacteriophages MS-2, $\Phi X-174$ and their hosts Escherichia coli (E. coli) ATCC-15597 and ATCC-13706 respectively, were kindly provided by Prof. J ohn Dennehy, Associate professor, Biology department, Queens College, City University of New York (CUNY) (https://www.atcc.org)
The strains of E. coli ATCC-15597 and ATCC- 13706 were cultured on ATCC media, incubated overnight at $370^{\circ} \mathrm{C}$, and then sub-cultured for $4 \mathrm{~h}$ at $37^{\circ} \mathrm{C}$ [39]. The $4 \mathrm{~h}$ aged bacterial cultures of ATCC-15597 and ATCC-13706 were inoculated with MS-2 and $\Phi \mathrm{X}-174$ respectively and incubated overnight at $37^{\circ} \mathrm{C}$. The cell lysate was then harvested by centrifugation at $4000 \mathrm{rpm}$ for $30 \mathrm{~min}$ at $4^{\circ} \mathrm{C}$, and the supernatant filtered through a $0.45 \mu \mathrm{m}$ syringe filter and used immediately or stored at $-20^{\circ} \mathrm{C}$ as a phage stock [9].

\section{Phage quantification (antiviral activity assay)}

Plaque reduction assay was carried out by using the overlay technique (double agar layers) to monitor the antiviral activity of the PBS extracts. Briefly, the phage was mixed in a ratio of $1: 1(\mathrm{v} / \mathrm{v})$ with different crude aqueous extracts, of final concentrations of $0.08,0.32,1.28,5.12$, 24.8 and $81.92 \mathrm{mg} \mathrm{mL}^{-1}$, and incubated for $1.0 \mathrm{~h}$, at $4^{\circ} \mathrm{C}$ [40]. The mixture was added to soft agar containing the respective host bacteria at its exponential growth phase, and then vortexed and overlaid on a solidified plate. The top agar was then allowed to solidify, and incubated overnight at $37^{\circ} \mathrm{C}$. The plaques were counted and the $\log _{10}$ reductions in the active phages were determined Standard C-PC with final concentration of $0.0125,0.025,0.125,0.25$ and $0.5 \mathrm{mg} \mathrm{mL}^{-1}$, ribavirin and acyclovir $(0.008,0.032,0.128$, $0.512,2.048$ and $8.192 \mathrm{mg} \mathrm{mL}^{-1}$ ) were used as positive controls [34,41,42]. Each treatment was run in triplicates, and a mean value was calculated.

\section{Virion titrations}

Briefly, the phage was added to different concentrations of the crude PBS extracts in a ratio of (1:1) as described before, and incubated for $1 \mathrm{hr}$ at $4^{\circ} \mathrm{C}$. The mixture was then added to the bacterial host, vortexed, and incubated overnight at $37^{\circ} \mathrm{C}$ [27]. Phage concentration (virions titer) was determined. The measurement of concentration depends on the absorbance at 269 and $320 \mathrm{~nm}$, which was measured using a Unico UV-2000, UV-Vis spectrophotometer [29]:

Virions $/ \mathrm{ml}=\frac{\left(A_{269}-A_{320}\right) \times 6 \times 10^{16}}{\text { no. of bases } / \text { virion } \times \text { volume used }(\mathrm{ml})} \times 100 \times$ dilution

where: no. of bases/phage for MS-2=3569 [8] and that of $\Phi X-174=5386$. Finally, the reduction in activity was determined as a percentage of number of phages treated with different test solutions, compared to that of the control (untreated phage). As mentioned, positive controls were used, and each treatment was run in triplicates.

\section{Electron microscopy}

Samples of treated and untreated phages were examined by a transmission electron microscope (TEM). A drop of purified phage was applied to a copper grid, and stained with $2 \%$ uranyl-acetate for $5 \mathrm{~min}$, and then examined in TEM (JEOL JEM-2100, USA) at the Electron Microscopy Unit, Faculty of Agriculture, Mansoura University, Egypt (https:// http://emunit.mans.edu.eg/).

\section{Statistical analysis}

All values of antiviral activities (reduction in PFU and virion concentration) are reported as the mean of three replicates \pm standard error. The data was subject to oneway ANOVA, and the mean values were separated based on a Ducan test at 0.05 probability level, using the COSTAT 6.3 package. Correlation between the two techniques (plaque assay and clarity method) was determined as a Pearson correlation, using the XL-Stat (2014) package, and the obtained results were expressed as determinants of $R^{2}$ (determination coefficient). 
Table 1

THE AVERAGE VALUES OF SPECIFIC GROWTH RATE $(\mu)$, GROWTH DOUBLING PER DAY (Dd $\left.{ }^{-1}\right)$ AND GENERATION TIME (G) OF DIFFERENT TEST CYANOBACTERIAL SPECIES

\begin{tabular}{|l|c|c|c|}
\hline \multicolumn{1}{|c|}{ Algal species } & Specific growth rate $(\mu)( \pm \mathrm{SD})$ & $\begin{array}{c}\text { Doubling per day } \\
(\mathrm{Dd}-1)( \pm \mathrm{SD})\end{array}$ & Generation time $(\mathrm{G})( \pm \mathrm{SD})$ \\
\hline Anabeanaanomala & $0.163( \pm 0.0001)$ & $0.236( \pm 0.0002)$ & $4.24( \pm 0.003)$ \\
\hline Aphanizomenonfios-aquae & $0.156( \pm 0.0003)$ & $0.226( \pm 0.0004)$ & $4.44( \pm 0.008)$ \\
\hline Chrocococcusminimus & $0.186( \pm 0.001)$ & $0.268( \pm 0.001)$ & $3.73( \pm 0.019)$ \\
\hline Nostoc sp. & $0.201( \pm 0.001)$ & $0.290( \pm 0.001)$ & $3.45( \pm 0.014)$ \\
\hline Spirulinaplatensis & $0.178( \pm 0.001)$ & $0.257( \pm 0.006)$ & $3.89( \pm 0.095)$ \\
\hline Synechococcuscearorum & $0.228( \pm 0.001)$ & $0.328( \pm 0.006)$ & $3.04( \pm 0.003)$ \\
\hline
\end{tabular}

Table 3

IR SIGNIFICANT BANDS OF THE LYOPHILIZED CRUDE

\section{Results and discussions}

The specific growth rate $(\mu)$ of different cyanobacterial species, divisions per day $\left(\mathrm{Dd}^{-1}\right)$, and the generation time (G) are listed in Table 1. The cyanobacterium Synechococcus cedrorum maintained the highest specific growth rate $(\mu=0.228 \pm 0.001)$, while Aphanizomenon flos-aquae maintained the lowest one $(0.156 \pm 0.0003)$. Growth doubling fluctuated within a narrow range of 0.226 $\mathrm{Dd}^{-1}$ (Aphanizomenon flos-aquae) and $0.328 \mathrm{Dd}^{-1}$ (Synechococcus cedrorum).

Phycobiliprotein pigments include C-phycocyanin (C$P C)$, allophycocyanin (APC), and phycoerythrin (PE). Absorbance of the PBS pigments at different wavelengths, concentration of each pigment, and the purity of C-PC are listed in Table 2. The total PBS fluctuated within a wide range of $0.195 \mathrm{mg}^{\mathrm{mL}} \mathrm{L}^{-1}$ (Synechococcus cedrorum), and $0.008 \mathrm{mg}^{\mathrm{mL}} \mathrm{m}^{-1}$ (Nostoc sp.). The highest concentration of C-PC was recorded for Synechococcus cedrorum followed by Spirulina platensis, while the highest PE concentration was recorded for Aphanizomenon flos-aquae. The purity ratio $\left(A_{62} / A_{280}\right)$ of C-PC ranged between 0.206 (Anabeana anomala) and 1.588 ( $S$. platensis).

The IR spectra of $S$. platensis PBS were more or less identically similar to those of the pure C-PC. Data presented in Table 3, indicated consistent similarity between bands of amide $\mathrm{C}=\mathrm{O}, \mathrm{N}-\mathrm{H}$ and $\mathrm{C}-\mathrm{N}$ bonds of both crude PBS of $\mathrm{S}$. platensis, and the pure C-PC.

Figure 1 illustrates two characteristic bands of the crude extract of Synechococcus cedrorum (Lane 1)
OBILIPROTEINS OF S. PLATENSIS AND PURE C-PHYCOCYANIN

\begin{tabular}{|c|c|c|c|}
\hline \multirow{2}{*}{ Sample } & \multicolumn{3}{|c|}{ Significant bands $\left(\mathrm{cm}^{1}{ }^{1}\right)$} \\
\cline { 2 - 4 } & N-H & $\begin{array}{c}\mathrm{C}=\mathrm{O} \text { of } \\
\text { amide }\end{array}$ & $\begin{array}{c}\mathrm{C}-\mathrm{N} \\
\text { stretchin }\end{array}$ \\
\hline PBS of S.platensis & 3460 & 1687 & 1125 \\
\hline Control: Pure C-PC & 3451 & 1660 & 1085 \\
\hline
\end{tabular}

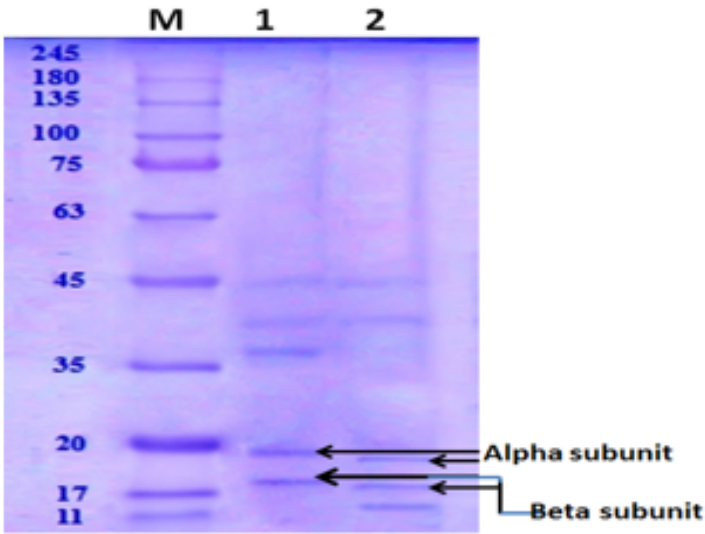

Fig. 1. Coomassie Brilliant blue-stained 14\% SDS-PAGE showing the protein electrophoresis pattern of the lyophilized crude extract of Synechococcu scedrorum using freezing and thawing extraction method, and the pure C-PC (Lane 1 and Lane 2, respectively).

M: BlueStar Plus pre-stained protein ladder (MWP04, NIPPON GENETICS); (11, 17, 20, 25, 35, 45, 63, 75, 100, 135, 180, and $245 \mathrm{kDa})$

Table 2

SPECTROPHOTOMETRIC ABSORBANCE FOR QUANTITATIVE DETERMINATION OF PBS CONCENTRATIONS AND PURITY RATIO OF PHYCOCYANIN POST FREEZING AND THAWING EXTRACTION METHOD FROM THE SIX TESTED CYANOBACTERIAL SPECIES

\begin{tabular}{|c|c|c|c|c|c|c|c|}
\hline \multicolumn{2}{|c|}{ Algal species } & $\begin{array}{l}\text { Anabeana } \\
\text { anomala }\end{array}$ & $\begin{array}{c}\text { Aphanizomenon flos- } \\
\text { aquae }\end{array}$ & $\begin{array}{c}\text { Chrocococcus } \\
\text { minimus }\end{array}$ & Nostoc sp. & S.platensis & $\begin{array}{l}\text { Synechococcus } \\
\text { ceatrorum }\end{array}$ \\
\hline \multicolumn{2}{|c|}{ Purity $\left(A_{620} / A_{280}\right)$} & 0.206 & 0.470 & 0.089 & 0.312 & 1.588 & 0.790 \\
\hline \multirow[t]{4}{*}{$\overline{\mathrm{Abs}}$} & $\overline{A_{280}}$ & 0.160 & $\overline{0.071}$ & 0.045 & 0.125 & 0.365 & 1.304 \\
\hline & $\overline{A_{562}}$ & 0.168 & 0.086 & 0.060 & 0.005 & 0.594 & 0.551 \\
\hline & $\mathrm{A}_{652}$ & 0.159 & 0.297 & 0.047 & 0.002 & 0.349 & 0.280 \\
\hline & $\overline{A_{620}}$ & $\overline{0.816}$ & 0.183 & 0.676 & 0.039 & 0.374 & 1.033 \\
\hline \multirow{4}{*}{$\begin{array}{c}\text { Conc. } \\
(\mathrm{mg} / \mathrm{ml})\end{array}$} & $\overline{\mathrm{C}-\mathrm{PC}}$ & 0.017 & 0.010 & 0.007 & 0.007 & 0.079 & 0.169 \\
\hline & $\overline{\mathrm{APC}}$ & 0.025 & 0.010 & $\overline{0.006}$ & 0 & $\overline{0.047}$ & 0.013 \\
\hline & $\overline{\mathrm{PE}}$ & 0.010 & 0.028 & 0.003 & 0.001 & $\overline{0.013}$ & 0.014 \\
\hline & Tot. PBS & 0.052 & 0.048 & 0.016 & 0.008 & 0.139 & 0.196 \\
\hline
\end{tabular}

N.B. C-PC: C-phycocyanin, APC: Allophycocyanin, PE: Phycoerthrin and PBS: Phycobiliprotein pigments. 
corresponding to 18 and $19.5 \mathrm{KDa}$ for the áand $\beta$ sub-units, respectively. Also, two sub-units of the pure C-PC, the $\alpha$ (16 KDa) and the $\beta$ subunit (17.5 KDa) are shown. The selection of Synechococcus extract for SDS-PAGE analysis is based on the fact that its PBS was the richest in C-PC, Table 2, compared to other cyanobacteria, in addition to its high antiviral potential.

The antiviral activity of the cyanobacterial PBS crude aqueous extracts was detected by plaque reduction assay (PA) (Figure 2) and virion titration assay (Figure 3). The antiviral inhibition activities exhibit obvious $(p \leq 0.05)$ variations depending on assay technique, phage surrogate, viral drugs and PBS extracted from different test cyanobacteria. It is clear from Figure 2 and 3 that the antiviral activity of pure C-PC on MS-2 was significantly higher than the commercial viral drugs ACV and RBV. Compared to these drugs, marked $\Phi X-174$ activity inhibition was evident, at $0.5 \mathrm{mg} \mathrm{mL}^{-1}$ of C-PC. According to the results of the PA (Figure 2), the aqueous crude PBS extracted from the cyanobacterium Synechococcus cedrorum (Fig. 21) followed by Anabeana anomala (Fig. 2D), Spirulina platensis (Fig. 2H) and Aphanizomenon flosaquae(Fig. 2E) exhibited significantantiviral activity against $\Phi X-174$. Compared to pure C-PC, antiviral drugs, and extracted PBS, the crude PBS extracted from Spirulina platensis maintained significantinhibition against MS-2 (Fig. 2H).

Similar result trends are obtained by virion titration (spectrophotometric method) (Fig. 3). Compared to the negative control (phage and bacterial host), ACV inhibited MS-2 activity between 3.75 and $40.08 \%$ corresponding to the doses 0.008 and $8.192 \mathrm{mg} \mathrm{mL}^{-1}$ respectively (Fig. 3B). However, RBV inhibited the MS-2 bacteriophage by 30.01 and $36.75 \%$ at doses 0.008 and $8.192 \mathrm{mg} \mathrm{mL}^{-1}$ respectively (Fig. 3C). Both drugs maintained relatively low antiviral activity against $\Phi \mathrm{X}-174$ with \% of inhibition ranging between 0.0 and $15.74 \%$. Compared to the negative control, the inhibition (\%) of different cyanobacterial PBS extracts on the MS-2 phage ranged between $32.23 \%$ (Chroococcus minimus, Fig. 3F) and $87.89 \%$ (S. platensis, Fig. 3H), and fluctuated from $17.97 \%$ (Nostoc sp., Fig. 3G) to $98.23 \%$ (Synechococcus cedrorum, Fig. 31). The highest $\%$ of inhibition ( $87.89 \%)$ of the SSRNA MS phage was recorded for phycobiliproteins extracted from the cyanobacterium S. platensis (Fig. $3 \mathrm{H}$ ) followed by Synechococcus cedrorum (50.95\%, Fig. 3l), Aphanizomenon flos-aquae (45.19\%, Fig. 3E), Anabeana anomala (49.97 \%, Fig. 3D), and Nostoc sp. (41.23\%, Fig. $3 G)$. In case of the ssDNA $\Phi X-174$, the highest $\%$ of inhibition $(98.23 \%)$ was maintained by PBS extract of the cyanobacterium Synechococcus cedrorum, Fig. 31, followed by Anabeana anomala (95.29 \%, Fig. 3D), S. platensis (93.62\%, Fig. 3H), Aphanizomenon flos-aquae (88.85\%, Fig. 3E), Chroococcus minimus (39.38\%, Fig. 3F) and Nostoc sp. (33.65 \%, Fig. 3G).

Figure 4 presents a clear comparison between the antiviral activities of different cyanobacterial PBS extracts
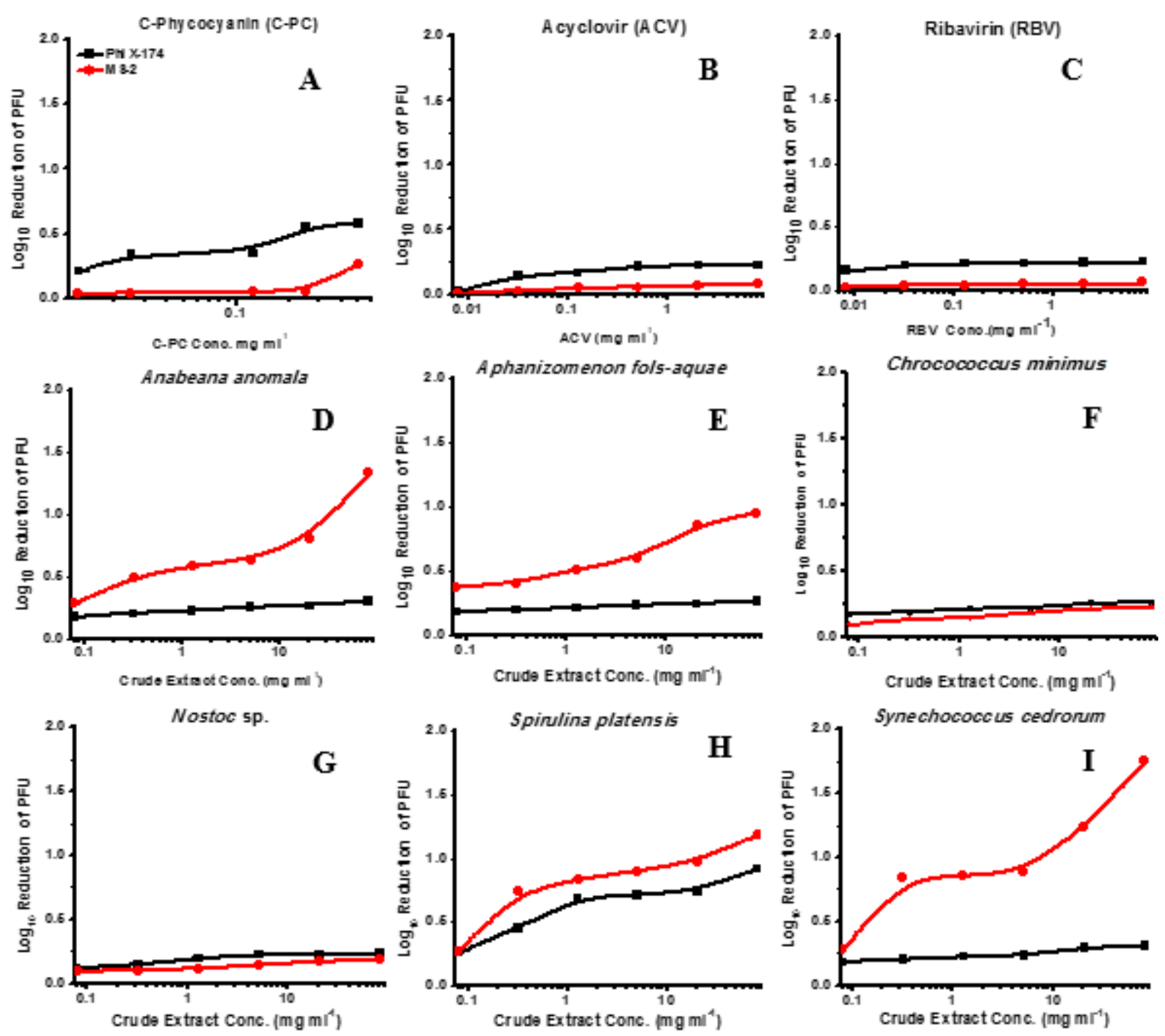

Fig. 2. The antiviral activity of the cyanobacterial phycobiliproteins compared with pure C-phycocyanin, acyclovir and ribavirin (positive controls) on the bacteriophage surrogates MS-2 and $\Phi X-174$ using plaque reduction assay (log10 reduction factor, LR) 

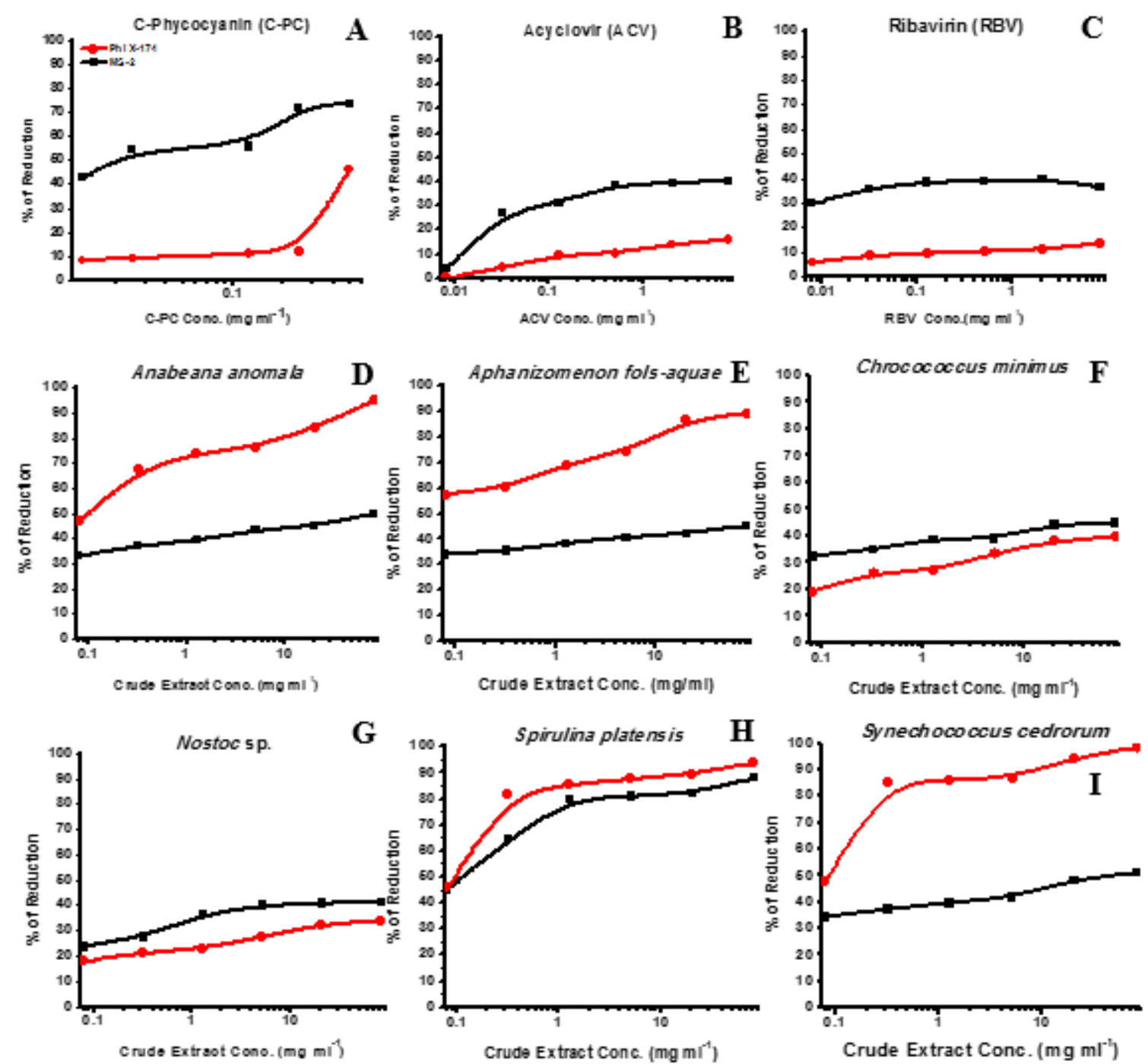

Fig. 3. Antiviral activity of the cyanobacterial phycobiliproteins compared with pure C-phycocyanin, acyclovir and ribavirin (positive controls) on the bacteriophage surrogates MS-2 and $\Phi X-174$ using \% of the reduction in virion concentration

on MS-2 phage using PA (Fig. 4A), and the spectrophotometric virion titration technique (Fig. 4B). The antiviral effects on the virulence of $\Phi X-174$ using PA and the virion titration method are illustrated in Figure $4 \mathrm{C}$ and $4 \mathrm{D}$, respectively. The figure clearly displays great similarity between LR and \% of inhibition as two different assays to monitor the effects of different cyanobacterial PBS on the activity virulence of MS-2, (Fig. 4A and B) and $\Phi X-174$ (Fig.
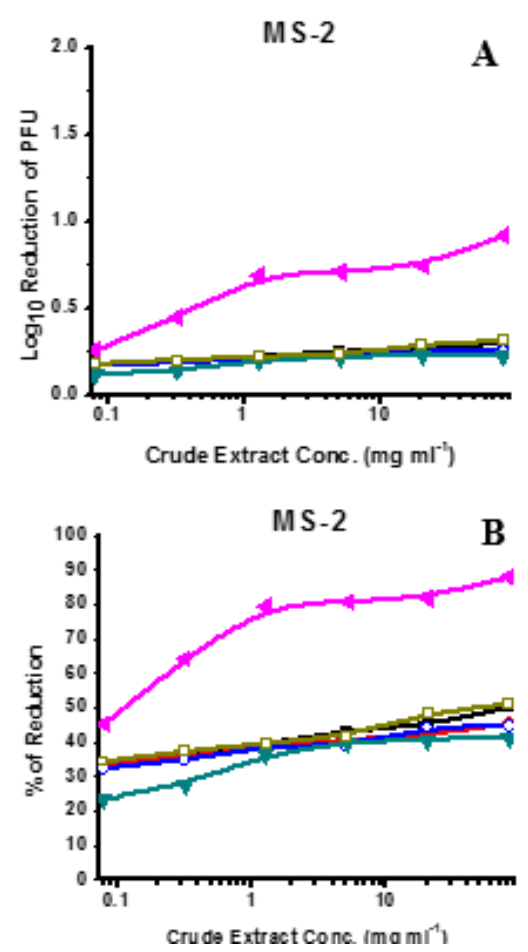

REV.CHIM. (Bucharest) $\bullet 70 \diamond$ No. $9 \diamond 2019$
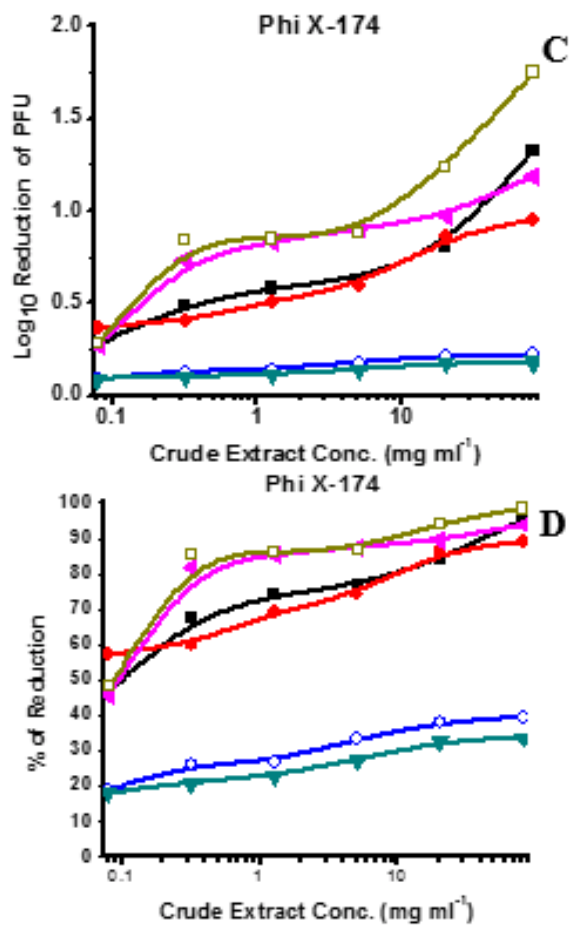

http://www.revistadechimie.ro
Fig. 4. Antiviral effects of different concentrations of six cyanobacterial crude extracts against MS-2 (A, B) and $\Phi X-174$ (C, D) using Log10 reduction factor (LR) of PFU and percent of reduction in virions 
$4 C$ and D). The obvious antiviral similarities displayed in Figure 4 was confirmed with significant $(p \leq 0.05)$ and very strong correlation between the two assays, monitoring the antiviral activities of different cyanobacterial PBS extracts against MS-2 $\left(R^{2}=0.94\right)$ and $\Phi X-174\left(R^{2}=0.90\right)$.

Based on the above results it is evident that the crude aqueous PBS extract of $S$. platensis maintained strong antiviral activities against both phages, MS-2 and $\Phi X-174$ (Figure 4H). In addition, the extract maintained the highest PBS purity, (Table 2). Accordingly, studies were done to follow up on the impact on morphological changes in the two phages, after treatment with PBS extract at the highest dose (81.92 mg.mL $\left.{ }^{-1}\right)$ giving the highest viral inhibition. Examination with transmission electron microscopy (TEM) was carried out to study the morphological changes in MS2, $\Phi X-174$ and their hosts after treatment with the PBS crude extract of $S$. platensis $\left(81.92 \mathrm{mg} \cdot \mathrm{mL}^{-1}\right)$. The icosahedral structure of MS-2 (Figure 5A), and $\Phi X-174$ (Figure $5 C$ ), bacteriophages was highly affected after 1.0 hour of incubation with the extract at $4^{\circ} \mathrm{C}$, which is clear in Figure $5 \mathrm{~B}$ and $5 \mathrm{D}$. It was also found that the adsorption of phages on their host cells one hour after the treatment was affected, compared to the untreated phages (Figure 6), where there was a decrease in the number of phage particles in both models than the control. The lysis of $E$. coli C (ATCC-15597) by $\Phi X-174$ phage activity is illustrated in Figure 7.

Studying the epidemiology and management of viral infection, especially virulent viruses as HIV and HCV, requires some restrictions imposed by their antiviral assays.
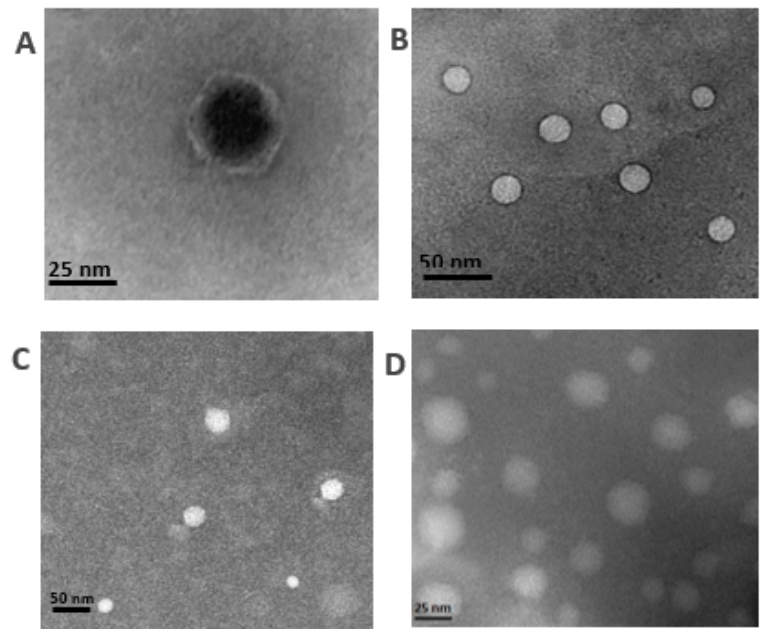

Fig. 5. Electron micrographs of MS-2 and $\Phi X-174$ bacteriophage stained with $2 \%$ uranyl acetate showing the morphological characters of the virion before and after treatment with the crude phycobiliproteins extract of Spirulina platensis. A: The MS-2 phage was naked icosahedral and tailless with average diameter $24 \mathrm{~nm}$. Bar corresponds to $25 \mathrm{~nm}$; B: MS-2 bacteriophage coated with the extract after $1 \mathrm{~h}$ of incubation at $4{ }^{\circ} \mathrm{C}$. Bar corresponds to $50 \mathrm{~nm}$; C: The $\Phi X-174$ phage was naked icosahedral capsid with diameter 27

$\mathrm{nm}$ without envelope or tail. Bar corresponds to $50 \mathrm{~nm}$; D:

Irregular architecture of the $\Phi X-174$ icosahedron after $1 \mathrm{~h}$ incubation with the PBS extract at $4^{\circ} \mathrm{C}$. Bar corresponds to $25 \mathrm{~nm}$.

The ever-evolving viral drug resistance, and their serious immune reactions, necessitate an urgent, serious need for drug alternatives. Peculiar structural characteristics, replication strategies, non-pathogenicity and ease of detection along with the economic feasibility of MS-2 (surrogate of enterovirus and HAV) and $\Phi X-174$ (surrogate of HBV, HCV and HIV) bacteriophages qualify them as ideal models of virulent mammalian viruses in antiviral assays. The present study screens the antiviral potentialities of
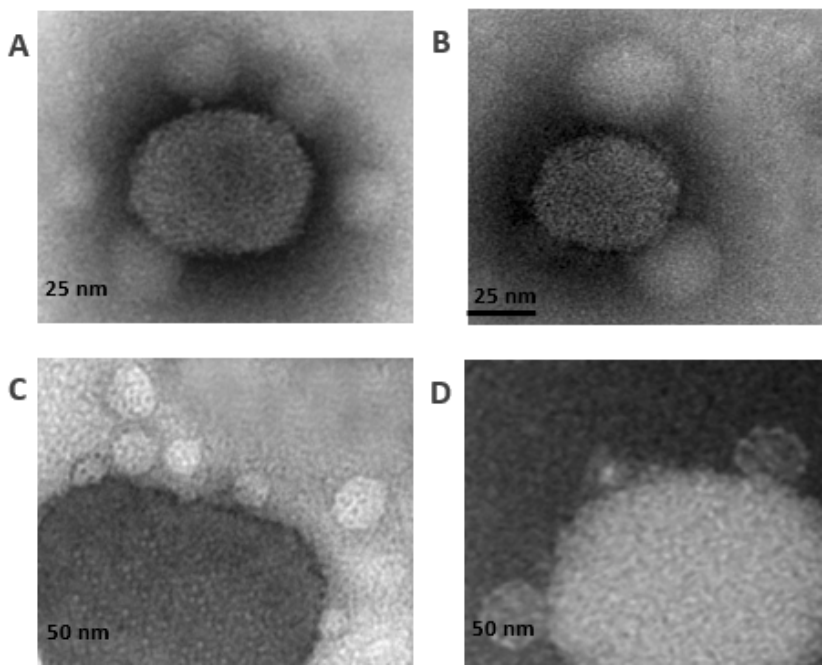

Fig. 6. Electron micrographs of the two phages with their bacterial host before and after treatment with Spirulina platensis

phycobiliproteins crude extract. A: MS-2 phages attaching to F-pilus of $E$. coli C3000 (ATCC-15597). Bar corresponds to $25 \mathrm{~nm}$; B

Adsorption of MS-2 phages to its bacterial host after $1 \mathrm{~h}$ of extract treatment; C: $\Phi \mathrm{X}-174$ phages binding to outer membranes of $E$. coli C (ATCC-13706). Bar corresponds to $50 \mathrm{~nm}$; D: Adsorption of $\Phi X-174$ phages to its bacterial host after $1 \mathrm{~h}$ of extract treatment

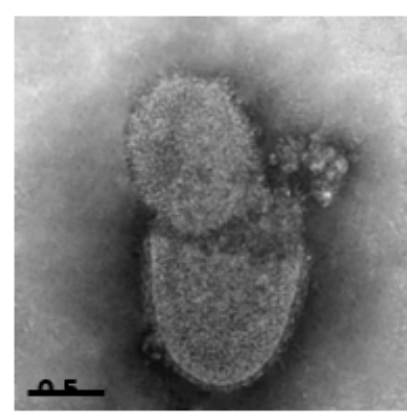

Fig. 7. Electron micrograph of $E$. coli C (ATCC-15597) negatively stained with $2 \%$ uranyl acetate showing the lysis phenomenon due to $\Phi X-174$ phage activity. Bar corresponds to $500 \mathrm{~nm}$

some PBS against MS-2 and $\Phi \mathrm{X}-174$ using the spectroscopic technique (virion titration) in the detection of antiviral activity as a promising technique. The choice of cyanobacterial PBS based on previous research [27] demonstrates the importance of cyanobacteria as a vital and rich renewable biosource, of a variety of antiviral drugs.

The physico-chemical studies indicate that the main active component was the C- phycocyanin where the IR spectra of lyophilized crude PSB of the tested cyanobacteria showed the primary significant bands of PC with the occurrence of bands at range of $\left(3500-3000 \mathrm{~cm}^{-1}\right)$, (1640$\left.1680 \mathrm{~cm}^{-1}\right)$ and $\left(1020-1200 \mathrm{~cm}^{-1}\right)$, confirming the presence of $\mathrm{N}-\mathrm{H}$ bond, the specific protein amide I group $(\mathrm{C}=0)$ and C-N bond, respectively. These findings are similar to the spectra of the control C-PC and those reported earlier [44], thus indicating the presence of the major component of the crude extracts as C-PC. The sharp band indicates the presence of an $\alpha$-helix as the main element of its protein secondary structure. SDS-PAGE analysis of the crude C-PC showed two bands corresponding to $\alpha$ and $\beta$ subunits of the pure C-PC which confirms its purity and homogeneity. The molecular weight of $\alpha$ and $\beta$ subunits was 19500 and 18000 , respectively, which is in the range of the findings of other research [45].

Allophycocyanin extract was found to inhibitenterovirus 71-induced cytopathic effects, viral plaque formation, and viral-induced apoptosis [27]. The crude C-PC extract of $S$. platensis was also reported to inhibit activities against certain viruses (New castle virus, Avian adenovirus, HAV and Polio virus) [44]. Both studies relied on testing the activity of the extracts in cell culture, which impose human 
significant risks associated with occupational exposure to viruses and increasing the likelihood of viral infection [2]. Therefore, viral assays with bacteriophage surrogates may be a powerful tool for screening new antiviral agents as they are safe to deal with, easily cultured, detectable with laboratory methods, rapid (18-24 h), and inexpensive [4648].

It is clear from the results obtained (Fig. 3 and 4) that different cyanobacterial PBS exhibited significantly different antiviral activities. This may be attributed to different compositions of cyanobacterial PBS and in particular to their relative mass ratios and purity. Supporting results reported by Harden et al. [37] found significant variation of virucidal activities of polysaccharide extracts of four different al gal species against herpes simplex virus. In this context, Kok et al. [49] have also reported widely different inhibitory effects of microalgal extracts against the Epstein-Barr virus. The most peculiar and interesting findings was the significantly higher anti-activity of cyanobacterial PBS on both MS-2 and $\Phi X-174$ compared with the two tested drugs ribavirin and acyclovir. These findings highlight the test cyanobacteria as promising bioresources for exploring novel antiviral compounds. Also, the relatively higher antiviral efficiencies of different PBS extracts compared to the pure C-PC can support the hypothesis that the purification and fractionation of C-PC can induce loss of the synergetic effect of the compounds mixture found in the crude extract $[34,49]$.

A very interesting observation was the marked strong inhibitory effects of PBS of Spirulina platensis against both MS-2 (87.89 \%, Fig. 4H) and $\Phi X-174(93.62 \%$, Fig. 4H). Based on this significant outcome, Spirulina platensis may hold a promising future for the discovery of new effective antiviral drugs. In this respect, it was reported [34] a potential antiviral activity of C-PC extracted from Spirulina platensis. Moreover, the fact that Spirulina platensis is a super-human food lends itself to the superiority of this cyanobacterium as a potential, renewable, bio-source of a variety of safe health drugs against fetal human viruses.

The results indicated that virion titration technique exhibit narrow variations among different cyanobacterial extracts (Fig. 5D) while these variations were high significance in case of plaque reduction assay (PA) (Fig. $5 \mathrm{C})$. This finding may indicate a higher sensitivity of virion titration compared to PA. This can also be supported by the fact that the PA is dependent on visually counting the plaques and therefore, may involve great personal error. However, the virion titration technique is an instrumental spectrophotometric method that exhibits higher sensitivity and low deviation errors. Accordingly, this technique can preferably substitute the classical PA in viral assays. In this respect, Adams indicated [20] that even though the traditional plaque assay is the current standard for quantitating phage titers, the obtained results may be significantly influenced by various factors.

The transmission electron microscope (TEM) micrographs elucidate the characteristic morphology of the purified MS-2 (Fig. 6A) and $\Phi X-174$ (Fig. 6C) bacteriophages. The icosahedral capsid of MS-2 had a size of approx. $24 \mathrm{~nm}$ that agrees with previous studies [49], while the icosahedron of $\Phi X-174$ was about $27 \mathrm{~nm}$ [10]. It is clear that the highest concentration of the $S$. platensis crude extract ( $81.92 \mathrm{mg} \mathrm{mL}^{-1}$ ) induced marked morphological changes on both MS-2 and $\Phi X-174$ compared to the control; where the characteristic icosahedral structures of their capsid became slightly spherical in shape. The Spirulina platensis extractexhibited a great effect on the phage adsorptions onto their hosts as indicated by marked reduction in the number of adsorbed phages of either MS-2 (Fig. 7B) and $\Phi X-174$ (Fig. 7D) in contrast to the untreated phages. This finding can correspond to the high reduction in phages titer of MS-2 (87.89\%) and $\Phi X-174$ (93.62 \%). The results clearly revealed that, the mode of action of Spirulina platensis PBS is assumed to interfere with the phage adsorption or penetration processes, i.e. the viral inhibition occurred at the early stage of the viral infection. The investigated cyanobacterial PBS seem to exhibit an antiviral mode of action disturbing the early stage of the viral life cycle with higher antiviral potential compared to the commercial medications ( $A C V$ and RBV).

\section{Conclusions}

The present study can provide a pioneering direction in the efforts for screening the antiviral activities of cyanobacterial phycobiliproteins against MS-2 and $\Phi X-174$ bacteriophage surrogates simulating virulent, fatal human viruses.

Acknowledgements: We are immensely grateful to Prof. John Dennehy (City University of New York, Queens College, New York City, United States of America) for providing the phages and to the Biotech International Research and Development (BIRD) center (Mansoura City, Egypt) for providing the cyanobacterial species.

\section{References}

1.HENDRIX, R.W., Theor. Popul. Biol., 61, 2002, p. 471.

2.ARANHA-CREADO, H., BRANDWEIN, H., PDA J. Pharmaceutic. Sci. Technol., 53, 1999, p. 75.

3.HU, W.-S., AUNINS, J. G., Current Opinion Biotechnol., 8, 1997, p. 148.

4.JAIN, R., SRIVASTAVA, R., BMC Systems Biol., 3, nr. 121, 2009, doi: 10.1186/1752-0509-3-121.

5.PAYMENT, P., FRANCO, E., Appl. Environ. Microbiol., 59, 1993, p. 2418.

6.GRABOW, W., Water S. A., 22, 1996, p. 193.

7.KUZMANOVIC, D.A., ELASHVILI, I., WICK, C., O'CONNELL, C., KRUEGER, S., Structure, 11, 2003, p. 1339.

8.BRENTLINGER, K.L., HAFENSTEIN, S., NOVAK, K.R., FANE, B.A., BORGON, R., MCKENNA, R., AGBANDJ E-MCKENNA, M., J. Bacteriol., 184, 2002, p. 1089.

9.HAYASHI, M., Cold Spring Harbor Monograph. Arch., 8, 1978, p. 531. 10.BENNETT, A., MCKENNA, R., AGBANDJ E-MCKENNA, M., Comput. Math. Meth. Med., 9, 2008, p. 183.

11.CROTTY, S., CAMERON, C., ANDINO, R., J. Molec. Med., 80, 2002, p. 86.

12.FEIGELSTOCK, D.A., MIHALIK, K.B., FEINSTONE, S.M., Virol. J ., 8, nr. 402, 2011, doi: 10.1186/1743-422X-8-402

13.IBARRA, K.D., J AIN, M.K., PFEIFFER, J.K., J. Virol., 85, 2011, p. 7273.

14.BHADURY, P., WRIGHT, P.C., Planta, 219, 2004, p. 561

15.DAHMS, H.-U., YING, X., PFEIFFER, C., Biofouling 22, 2006, p. 317. 16.ABDEL-DAIM, M.M., ABUSHOUK, A.I., ALKHALF, M.I., TORAIH, E.A., FAWZY, M.S., IJ AZ, H., ALEYA, L., BUNGAU, S., Envron. Sci. Pollut. Res. Int., 25, nr. 27, 2018, p. 27463. https://doi.org/10.1007/s11356-0182761-0

17.LEE, J.-B., SRISOMPORN, P., HAYASHI, K., TANAKA, T., SANKAWA, U., HAYASHI, T., Chem. Pharm. Bull. (Tokyo), 49, nr. 1, 2001, p. 108. 18.LEE, J.-B., HAYASHI, K., MAEDA, M., HAYASHI, T., Planta Medica, 70, 2004, p. 813.

19.ZHANG, T., GONG, H., WEN, X., LU, C., J. Plant Physiol. 167, 2010, p. 951.

20.MACCOLL, R., J. Struct. Biol., 124, 1998, p. 311.

21.GANTT, E., Rev. Plant. Phwiol., 32, 1981, p. 327.

22.PATIL, G., RAGHAVARAO, K., Biochem. Eng. J., 34, 2007, nr. 156.

23.BHAT, V.B., MADYASTHA, K., Biochem. Biophys. Res. Commun., 285, 2001, p. 262. 
24.FAROOQ, S.M., EBRAHIM, A.S., SUBRAMHANYA, K.H., SAKTHIVEL, R., RAJESH, N.G., VARALAKSHMI, P., MOLEC. CELL. BIOCHEM., 284, NR. 1-2, 2006, P. 95.

25.SHIH, S.R., TSAI, K.N., LI, Y.S., CHUEH, C.C., CHAN, E.C., J. Medic.Virol., 70, 2003, p. 119.

26.ADAMS, M.H., Methods time measurement ASSN for standards and research, 16-01 Broadway, Fair Lawn, NJ 07410, 1950.

27.VERMA, S.K., Production of single chain fragment variable (ScFv) monoclonal antibodiy for Sclerotium rolfsii lectin using phage display technology, UAS, Dharwad, 2009.

28.OSMAN, Y., EL-MORSI, A., ELWAKIL, M., OMER, F., J. Environ. Sci. Technol., 7, nr. 67, 2014, p. 67.

29.WARNER, C.M., BARKER, N., LEE, S.-W., PERKINS, E.J ., Bioprocess Biosyst. Eng., 37, 2014, p. 2067.

30.PELIZER, L.H., DANESI, E.D.G., O'RANGEL, C., SASSANO, C.E.N., CARVALHO, J.C.M., SATO, S., MORAES, I.O., J. Food Eng., 56, 2003, p. 371.

31.WALTER, C., STEINAU, T., GERBSCH, N., BUCHHOLZ, R., Biomolec. Eng., 20, 2003, p. 261.

32.MURUGAN, T., J. Pharm. Res., 4, nr. 11, 2011, p. 4161.

33.PATEL, A., MISHRA, S., PAWAR, R., GHOSH, P. Purification and characterization of C-phycocyanin from cyanobacterial species of marine and freshwater habitat. Protein expression and purification 40, 248-255 (2005).

34.SINGH, P., KUDDUS, M., THOMAS, G., Int. Res. J. Biotechnol., 1, 2010, p. 080.

35.J OHNSON, E.M., KUMAR, K., DAS, D., Bioresource Technol., 166, 2014, p. 541.

36.KLIEVE, A.V., in Methods in Gut Microbial Ecology for Ruminants, Springer Netherlands, 2005, pp. 39-46.
37.HARDEN, E.A., FALSHAW, R., CARNACHAN, S.M., KERN, E.R., PRICHARD, M.N., Antiviral Res., 83, 2009, p. 282.

38.I, Y., BUT, P.P., OOI, V. E., Antiviral Res., 68, 2005, p. 1.

39.WANG, H., LI, Y.-L., SHEN, W.-Z., RIU, W., WA, X.-J ., CHEN, Y.-Z., Botanica Marina, 50, 2007, p. 185.

40.LIN, N.-T., CHIOU, P.-Y., CHANG, K.-C., CHEN, L.-K., LAI, M.-J ., Res. Microbiol., 161, 2010, p. 308.

41.EL-BAKY, H.H.A., EL-BAROTY, G.S., Food \& Function, 3, 2012, p. 381.

42.BENEDETTI, S., RINALDUCCI, S., BENVENUTI, F., FRANCOGLI, S., PAGLIARANI, S., GIORGI, L., MICHELONI, M., D'AMICl, G.M., ZOLLA, L., CANESTRARI, F., J. Chromatography B, 833, 2006, p. 12.

43.LEPAGE, C., ROMOND, C., Pathol.-Biol., 32, 1984, p. 631.

44.GRABOW, W., Water Sa, 27, 2001, p. 251-268.

45.ARDEN, N., BETENBAUGH, M.J., Trends Biotechnol., 22, 2004, p. 174.

46.KOK, Y.-Y., CHU, W.L., PHANG, S.M., MOHAMED, S.M., NAIDU, R., LAI, P.J., LING, S.N., MAK, J.W., LIM, P.K., BALRA,. P., KHOO, A.S., J. Zhejiang Univ. Sci. B., 12, 2011, p. 335.

47.KROPINSKI, A.M., MAZZOCCO, A., WADDELL, T.E., LINGOHR, E., JOHNSON, R.P., Enumeration of bacteriophages by double agar overlay plaque assay. Bacteriophages: Methods and Protocols, Vol. 1, Isolation, Characterization, and Interactions, 2009, pp. 69-76.

48.ARKHANGELSKY, E., GITIS, V., Separ. Purif. Technol., 62, 2008, p. 619.

49.PIERRE, G., CAUSSERAND, C., ROQUES, C., AIMAR, P., A., Desalination, 250, 2010, p. 762-766.

$\overline{\text { Manuscript received: } 7.01 .2019}$ 